Article

\title{
Teacher Training in Lifelong Learning-The Importance of Digital Competence in the Encouragement of Teaching Innovation
}

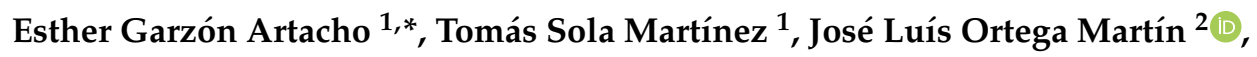 \\ José Antonio Marín Marín ${ }^{1}\left[\right.$ and Gerardo Gómez García ${ }^{1, *(1)}$ \\ 1 Department of Didactics and School Organization, University of Granada, 18071 Granada, Spain; \\ tsola@ugr.es (T.S.M.); jmarin@ugr.es (J.A.M.M.) \\ 2 Department of Didactics of Language and Literature, University of Granada, 18071 Granada, Spain; \\ ortegam@ugr.es \\ * Correspondence: esterga@correo.ugr.es (E.G.A.); gomezgarcia@ugr.es (G.G.G.); \\ Tel.: +34-958-248-397 (E.G.A.)
}

Received: 12 February 2020; Accepted: 1 April 2020; Published: 3 April 2020

\begin{abstract}
The vertiginous advance of society in recent years has forced a modification of demands among citizens and educators. The arrival of information and communication technologies to the educational atmosphere has led to the development of the digital competence of teachers, which is one of the educational challenges teacher training has to face now. Based on this, this work intends to carry out an evaluation of the development of digital competence in teachers of the Lifelong Learning stage in the community of Andalusia (Spain). In order to do so, a quantitative and transversal work design was used, with a sample of 142 teachers from different schools in this area. The results showed a deficit of teachers in the five digital dimensions, especially in the creation of digital content. It was also clarified that there was a direct relationship between previous information and communication technology (ICT) training and the dimensions of communication and collaboration, and content creation. Finally, the work here showed that the teachers concerned with preservice ICT training were young and with less than 10 years of experience. In conclusion, the development of digital teaching competence continues to be a challenge for the education system which must therefore be addressed, and it shall continue to be a key issue in the training of current teachers, as it is indeed a fundamental pillar for promoting a new way of teaching, being the only way to develop an areal teaching innovation panorama.
\end{abstract}

Keywords: teacher training; digital competence; information and communication technologies; educational challenges

\section{Introduction}

In recent years, information and communication technologies (ICTs) have entered society, causing numerous changes to the social and economic levels, and without any doubt, to the educational one. The reality of its arrival has led to a change in educational plans, whose lines needed to be adapted to an innovative training where culture and digital practice is predominant [1]. ICTs permeate our daily lives, and their use is becoming a fundamental requirement for insertion and promotion in the workplace, for learning autonomy, and for encouraging the practice of active citizenship [2,3].

If we proceed to make a demographic distinction of the different web users that exist on the net, we can distinguish, on the one hand, those who have grown up around technology, called digital natives, and therefore, who have interacted with the digital environment from the beginning of their lives, and on the other hand, those who were adults when ICTs entered their lives, called digital 
immigrants by experts, and who have grown up in an analogue environment. These are the ones the new technological tools and multimedia language need to be shown to, in order to promote their active participation in the new information society in which we currently live [4].

If we take a look at the educational landscape, the presence of ICTs is increasing within classrooms at different educational stages [5-7]. For this reason, many experts have stated that the development of digital teaching skills is a challenge to be faced by future generations and a challenge to be met in the face of the quickly technological progress in which we live.

In this sense, the Horizon Report outlines how technology and digital tools are everywhere; however, they can be ineffective when they are not integrated into the learning process in a meaningful way [8]. In relation to this idea, along the lines of educational improvement, the Sustainable Development Goals (SDG) are beginning to be linked to different educational areas. The goals have been defined by the United Nations as part of its Sustainable Development Agenda 2030, establishing a total of 17 goals where education and ICTs are key to their achievement. Among the 17 goals, the one which has a most direct relation to education is SDG 4: Quality Education. For this reason, the concept of digital teacher competence is very relevant, understood as a skill that can improve their teaching process [9].

As a matter of fact, the importance of digital competence is also observed in the Digital Agenda for Europe, presented in the framework of the Europe 2020 strategy, where digital competence is reflected as a priority challenge to be faced by the educational community [10]. In this sense, digital competence has become one of the basic skills that every citizen must develop at the end of their basic education in the European sphere [11]. In the Spanish one, the INTEF (Instituto Nacional de Tecnologías Educativas y Formación del Profesorado (National Institute of Educational Technologies and Teacher Training)) is responsible for ensuring the development of an educational practice that promotes the inclusion of ICTs in the classrooms of multiple educational spaces, as well as the beginning of an initial and ongoing training in five specific competence areas [12] (Table 1).

Table 1. Competence areas that develop the Digital Teaching Competence. Source: [12].

$\begin{array}{ll}\begin{array}{l}\text { Information and Information } \\ \text { Literacy }\end{array} & \begin{array}{l}\text { Identify, locate, obtain, store, organize, and analyze digital information, } \\ \text { data, and digital content, which assess their purpose and relevance to } \\ \text { teaching tasks } \\ \text { Communication and Collaboration } \\ \text { Communicate in digital environments, share resources through online } \\ \text { tools, connect and collaborate with others through digital tools, interact } \\ \text { and participate in communities and networks, which all lead to } \\ \text { cross-cultural awareness } \\ \text { Create and edit new digital content, integrate and rework previous } \\ \text { knowledge and content, create artistic productions, multimedia content } \\ \text { and computer programming, to know how to apply intellectual } \\ \text { property rights and licenses for use } \\ \text { Acknowledge protection of information and personal data, protection of } \\ \text { digital identity, protection of digital content, as well as security } \\ \text { measures and a responsible and safe use of technology } \\ \text { Identify needs to use digital resources, make informed decisions about } \\ \text { the most appropriate digital tools according to the purpose or need, } \\ \text { solve conceptual problems through digital media, use technologies } \\ \text { creatively, solve technical problems, and update their own competence } \\ \text { and that of others }\end{array} \\ \text { Problem Solving } & \end{array}$

To sum up, it is relevant to review other definitions of digital competence that complement the previous one, distinguished in the following competences: 1-Technical competence; 2-Capacity to use digital technologies in a meaningful way for work; 3-Capacity to critically evaluate digital technologies; and 4-Motivation to participate in and commitment to digital culture [13].

In order to measure the development of existing digital literacy, various agencies have established measurement frameworks to determine a person's level of digital literacy. Among the most important 
are the Common Framework for the Digital Competence of Teachers in Spain [12], the European Framework for the Digital Competence of Educators-DigComp [14] or the ISTE standards [15]. In this way, in a process similar to that of determining language knowledge, it allows qualifying someone's level of digital competence based on their proven skills.

\subsection{The Importance of Lifelong Learning for the Promotion of Digital Literacy in Society}

The Law on Education in Andalusia specifies that continuing education is "the one which has the purpose of giving all persons over the age of eighteen the opportunity to acquire, update, complete or expand their knowledge and skills for their personal or professional development" [16].

The specific public centers for Adult Lifelong Learning are the CEPER-SEPER (Centros y secciones de Educación Permanente (Centers and Sections of Lifelong Learning)), the IPEP-SIPEP (Sección del instituto e instituto provincial de Educación Permanente (Institutes and Provincial Sections of Lifelong Learning)), the IESs (Institutos de Educación secundaria (Institutes of Secondary Education)), the EOIs (Escuela oficial de idiomas (Official Language Centers)) and the distance learning institutes of Andalusia. Focusing on the first typology, it is an organized institution, as it has a main center, and the rest of the centers depend on it. In this case, the main center is the CEPER, and the rest are the SEPERs. This type of center offers the obtaining of the basic training qualification or preparation for accessing to a professional training [17].

Likewise, these centers also promote nonformal educational plans in those training notions that are considered important today, as is the case of ICT training. They are included in the training for the development of an active citizenship, and they have the objective of encouraging interaction of adults with ICTs, to achieve an autonomous development in the information society. In brief, it is relevant to highlight some complementary free sections such as Andalucía Compromiso Digital (Andalusian Commitment to Digital Area), which offers an approach to a basic training in each of the dimensions of digital competence [18].

For this reason, the development of technological resources in different educational spaces promotes the need to identify the level of digital competence of the teaching body that provides it, in order to deeply study the possible limitations and to be able to create lines of improvement that encourage the correction of these competence difficulties [19]. It is crucial that educational innovation also take place in Lifelong Learning, since this is an educational stage that trains citizens who, in their majority, have not come into contact with ICTs before, and therefore, it is a period in which they learn basic skills that will allow them to develop autonomously in a technological environment. For these reasons, it is essential that teachers at this stage of education do not only rely on technological resources when teaching, but they also must have the necessary skills to understand the educational opportunities offered by ICTs and be able to effectively transmit them to their students [20,21].

\subsection{Background}

According to Cabero [22], the 21st-century teacher should be one who has a compendium of skills that allows them to guide students in their technology-assisted learning process.

The literature justifies the importance of producing works that measure the digital competence of teachers in order to take urgent and immediate action to meet the educational challenges of the future [23-26]. Thus, there is a great deal of research that has tried to cover the analysis of digital teacher competence in different subjects of the education system. On one hand, there are those who deal with the analysis of future teachers of preschool and primary education [27-32], whose results indicated that future teachers presented an intermediate level in the development of digital competence. Therefore, this is a basic level that may be enough for the self-determination of the future teacher in the topic, but it is not enough to teach digital practice to their future students. [28].

In this line, there are relevant studies $[33,34]$ that specify a deficient level in the informational area, research, selection, and collection of information. Additionally, they deal with the analysis of digital competence in active teachers, and among them, we can find a compendium of studies in 
different contexts that determine that teachers do not have enough digital skills according to the current demands of the information society [35,36].

Thus, among the dimensions that constitute digital teaching competence, the relevance of especially developing the dimensions of collaboration and communication and, fundamentally, that of content creation, which presents worse levels of development, stands out [37-39]. The results of these studies show that higher education teachers need to know the didactic usefulness of technological resources in order to encourage their use in the classroom.

At the same time, research on this subject also includes an analysis of factors that can be identified as possible incidents in the development of digital teaching skills such as the nature of the education center, which constitutes a determining factor in the development of digital teaching skills [40]. In turn, other variables such as gender, previous ICT training, teacher qualifications, teaching experience, and the sociocultural context may have a direct impact on the level of digital competence presented [41-46].

Finally, research in international contexts corroborates the scarcity of digital competence, especially when it comes to teachers being able to create their own digital content or share it with the rest of the teaching community [47-51]. The lack of this competence causes the limitation of the use of ICTs by teachers in their classrooms and turns it into a mere support tool in their traditional discourse. Therefore, special emphasis is placed on its development so that teachers can engage in new ways of teaching in the classroom, such as active methodologies supported by ICTs, such as project learning, problem-based learning, flipped classroom or mobile learning, all of which encourage active exercise by both teachers and students [38].

\subsection{Research Objetives}

As evidenced in the literature review, the level of digital competence in the teaching body varies depending on the context and stage of education. Based on the ideas presented, the objective of this work is to identify the level of digital competence in teachers of Lifelong Learning in the Autonomous Community of Andalusia (Spain). From this objective, the following specific objectives are also covered:

- Determining which are the areas in which Lifelong Learning teachers present a greater lack of knowledge.

- Verifying if there are significant differences in the development of teachers' digital competence according to the previous training that the analyzed teachers received on ICTs; and

- Analyzing what factors directly influence whether prior ICT training of teachers takes place.

\section{Materials and Methods}

The use of a cross-cutting methodology of a quantitative nature was advocated in order to obtain empirical data through the description of the educational reality. To this end, the application of different descriptive-inferential statistical measures was used to accurately describe subjects' responses $[52,53]$.

\subsection{Sample}

The population was composed of teachers within various public Lifelong Learning centers in the Autonomous Community of Andalusia, Spain. For the counting of the sample $(n=142)$, stratified random sampling was applied, which included teachers from different provinces of Andalusia (Granada, Huelva, Sevilla, Cádiz, Almería, and Córdoba) (Figure 1). The subjects were part of the CEPER-SEPER and IES that offer adult training. 


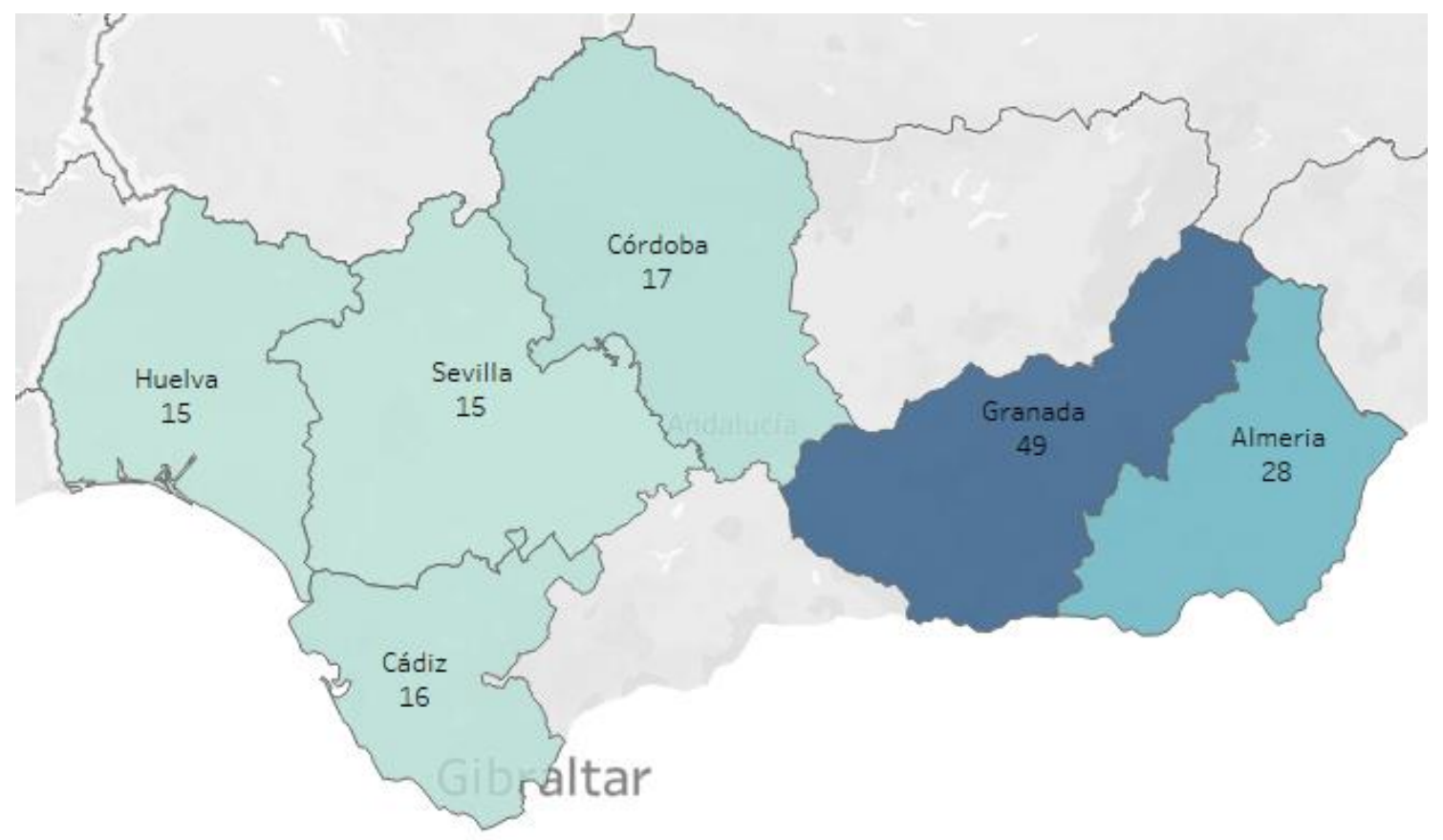

Figure 1. Origin of the sample of Lifelong Learning teachers.

Table 2 details the sociodemographic characteristics below.

Table 2. Characteristics of the study sample.

\begin{tabular}{ccc}
\hline Variable & Mean & SD \\
\hline Gender & 1.58 & 0.500 \\
Age & 35.40 & 8.595 \\
Previous ICT training & 1.285 & 0.453 \\
Teaching experience & 4.97 & 3.075 \\
\hline
\end{tabular}

\subsection{Instrument}

The instrument used was an ad hoc questionnaire based on existing dimensions of digital teacher competence. It consists of 91 items, differentiated as follows: 16 items on information and information literacy; 31 on communication and collaboration; 16 on digital content creation; 13 on digital security; and 15 on problem solving. The instrument's scale is of the Likert type, with 10 response options ( $1=$ never; 10 = always). The following is the coding that follows the different dimensions and the competencies that encompass them:

B.1. Information and Information Literacy

B.1.1. Navigation, search, and filtering of information

B.1.2. Evaluation of information and data and digital content

B.1.3. Storage and retrieval of information, and data and digital content

B.2. Communication and Collaboration

B.2.1. Interaction through digital technologies

B.2.2. Sharing information and digital content 
B.2.3. Online citizen participation

B.2.4. Collaboration through digital channels

B.2.5. Netiquette

B.2.6. Digital identity management

B.3. Creation of Digital Content

B.3.1. Development of digital content

B.3.2. Integration and reworking of digital content

B.3.3. Copyright and licenses

B.3.4. Programming

B.4. Security

B.4.1. Device protection

B.4.2. Protection of personal data and digital identity

B.4.3. Health protection

B.4.4. Environmental protection

B.5. Problem solving

B.5.1. Technical troubleshooting

B.5.2. Identification of technological needs and responses

B.5.3. Innovation and creative use of digital technology

B.5.4. Identification of gaps in digital competence

For the validation procedure, the instrument was subjected to a content analysis by multiple experts from the Universities of Málaga, Granada, and Sevilla. Subsequently, its internal consistency of the variables was corroborated through Bartlett's sphericity test $(\mathrm{KMO}=0.79 ; p<0.001)$.

With respect to the reliability of the instrument, it was analyzed through Cronbach's alpha coefficient $(\alpha=0.87)$ and the two Guttman halves (0.74), recording both optimal values, thus guaranteeing the adequate performance of the research.

\subsection{Procedure and Data Analysis}

Data collection was carried out in the first quarter of 2019 using a Google form. The instrument was distributed several times until a voluntary response was obtained from the sample of subjects through online channels. The statistical software SPSS 25.0 Version and RStudio 1.1383 version were used for data analysis.

Firstly, descriptive statistics were calculated in order to ascertain the subjects' perceptions of the level of digital competence. Subsequently, and after verifying the nature of the data distribution through the Kolmogorov-Smirnov and Shapiro-Wilk and Levene tests, the Mann-Whitney inferential $\mathrm{U}$ test and Wilcoxon's W test were applied in order to discover whether significant differences could 
exist between the subjects depending on the independent variable "Previous ICT training". Likewise, and with the intention of discovering the dependence between this same independent variable and the set of dependent variables, a predictive model was drawn up using the H2o and Local Interpretable Model-agnostic Explanations (LIME) algorithms to justify the incidence of the different variables of the study on previous ICT training.

\section{Results}

First, we proceeded to analyze the descriptive statistics (Table 3), which allowed us to approach the reality of the sample of subjects analyzed. The responses collected showed a low level of digital competence, and no average values were found that were equal to or greater than five (scale 1-10). The low level found in the dimension of digital content creation is especially noteworthy, as it presents a level close to zero. The best result was obtained in the security dimension, although it still does not reach the minimum needed to be considered optimal.

Table 3. Descriptive statistics.

\begin{tabular}{ccccc}
\hline Dimension & Mean & SD & Asym & Kurt \\
\hline B.1. & 3.239 & 1.616 & 1.221 & 1.637 \\
B.2. & 3.185 & 1.466 & 0.628 & 9.049 \\
B.3. & 1.843 & 0.966 & 2.046 & 5.885 \\
B.4. & 3.954 & 1.103 & -0.199 & -2.587 \\
B.5. & 3.695 & 1.096 & 0.592 & 0.134 \\
\hline
\end{tabular}

In order to carry out the inferential statistics, we previously resorted to normality and homogeneity of variances. The Kolmogorov-Smirnov and Shapiro-Wilk tests were applied, obtaining a result that corroborated that the distribution of the data collected did not correspond to the normal trend $(p<$ $0.01)$. Later, Levene's test was calculated which allowed us to corroborate the previous idea, since no equality between variances was obtained $(p>0.05)$.

Once these tests had been determined, nonparametric statistical measures were used. Specifically, the Mann-Whitney $U$ and Wilcoxon $W$ tests were used, which found that there were no significant differences in the development of digital competence of the teachers surveyed based on the independent variable "prior ICT training". Only the relationships between the independent variables and the communication and collaboration and digital content creation dimensions were considered significant $(p<0.05)$ (Table 4$)$.

Table 4. U Mann-Whitney based on the variable "previous ICT training".

\begin{tabular}{|c|c|c|c|c|c|c|}
\hline \multicolumn{2}{|c|}{ Dimension } & $\begin{array}{c}\text { Average } \\
\text { Range }\end{array}$ & U Mann-Whitney & $\begin{array}{c}\text { W. } \\
\text { Wilcoxon }\end{array}$ & $\mathbf{Z}$ & $p$ \\
\hline \multirow{2}{*}{ B.1. } & Yes & 70.796 & \multirow{2}{*}{1757.406} & \multirow{2}{*}{4522.795} & \multirow{2}{*}{-1.164} & \multirow{2}{*}{0.178} \\
\hline & No & 66.718 & & & & \\
\hline \multirow{2}{*}{ B.2. } & Yes & 72.214 & \multirow{2}{*}{1882.500} & \multirow{2}{*}{5080.790} & \multirow{2}{*}{-0.906} & \multirow{2}{*}{0.047} \\
\hline & No & 71.632 & & & & \\
\hline \multirow{2}{*}{ B.3. } & Yes & 69.613 & \multirow{2}{*}{1815.125} & \multirow{2}{*}{5278.875} & \multirow{2}{*}{-0.982} & \multirow{2}{*}{0.033} \\
\hline & No & 72.726 & & & & \\
\hline \multirow{2}{*}{ B.4. } & Yes & 71.690 & \multirow{2}{*}{1722.038} & \multirow{2}{*}{3019.269} & \multirow{2}{*}{-0.657} & \multirow{2}{*}{0.272} \\
\hline & No & 67.532 & & & & \\
\hline \multirow{2}{*}{ B.5. } & Yes & 70.471 & \multirow{2}{*}{1845.933} & \multirow{2}{*}{4639.933} & \multirow{2}{*}{-0.762} & \multirow{2}{*}{0.122} \\
\hline & No & 70.613 & & & & \\
\hline
\end{tabular}


In order to further specify the relationship of dependence of the variable "previous ICT training", the $\mathrm{H} 2 \mathrm{o}$ algorithm was used, with the aim of elaborating a model that would make it possible to explain the relationship between the dependent variables and the indicated independent variable (Figure 2). The distributed random forest model was used, whose $\mathrm{R}$ coefficient indicated $96 \%$ predictive reliability. The RMSE was 0.79 , so the difference between the original data and the predicted data was optimal.

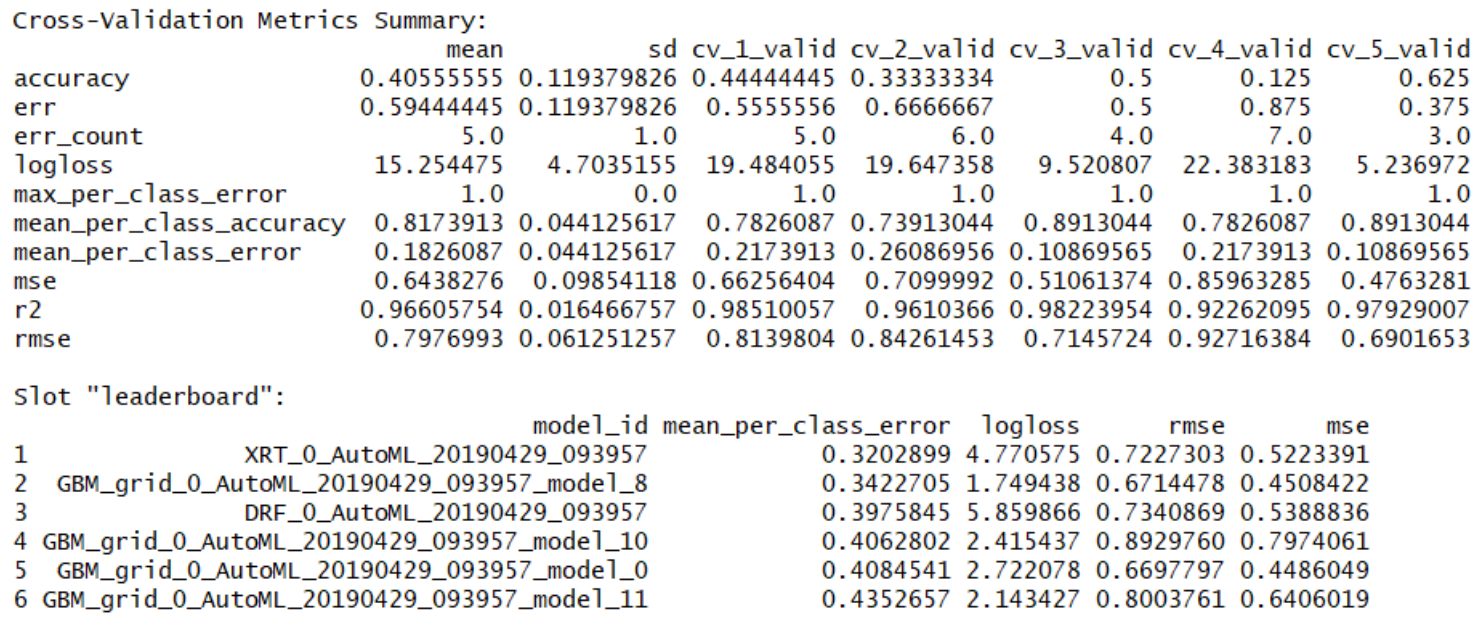

Figure 2. Model elaborated through the H2o algorithm.

Cross-validation using a multilayer perceptron was then used to further explore which factors had an impact on previous ICT training of the teachers analyzed (Figure 3). To do this, the LIME algorithm was used to show that the variable "age" is the one that most affects whether or not ICT training is carried out among teachers. In descending order, it is followed by aspects related to digital security, information and information literacy or the experience they have as teachers.

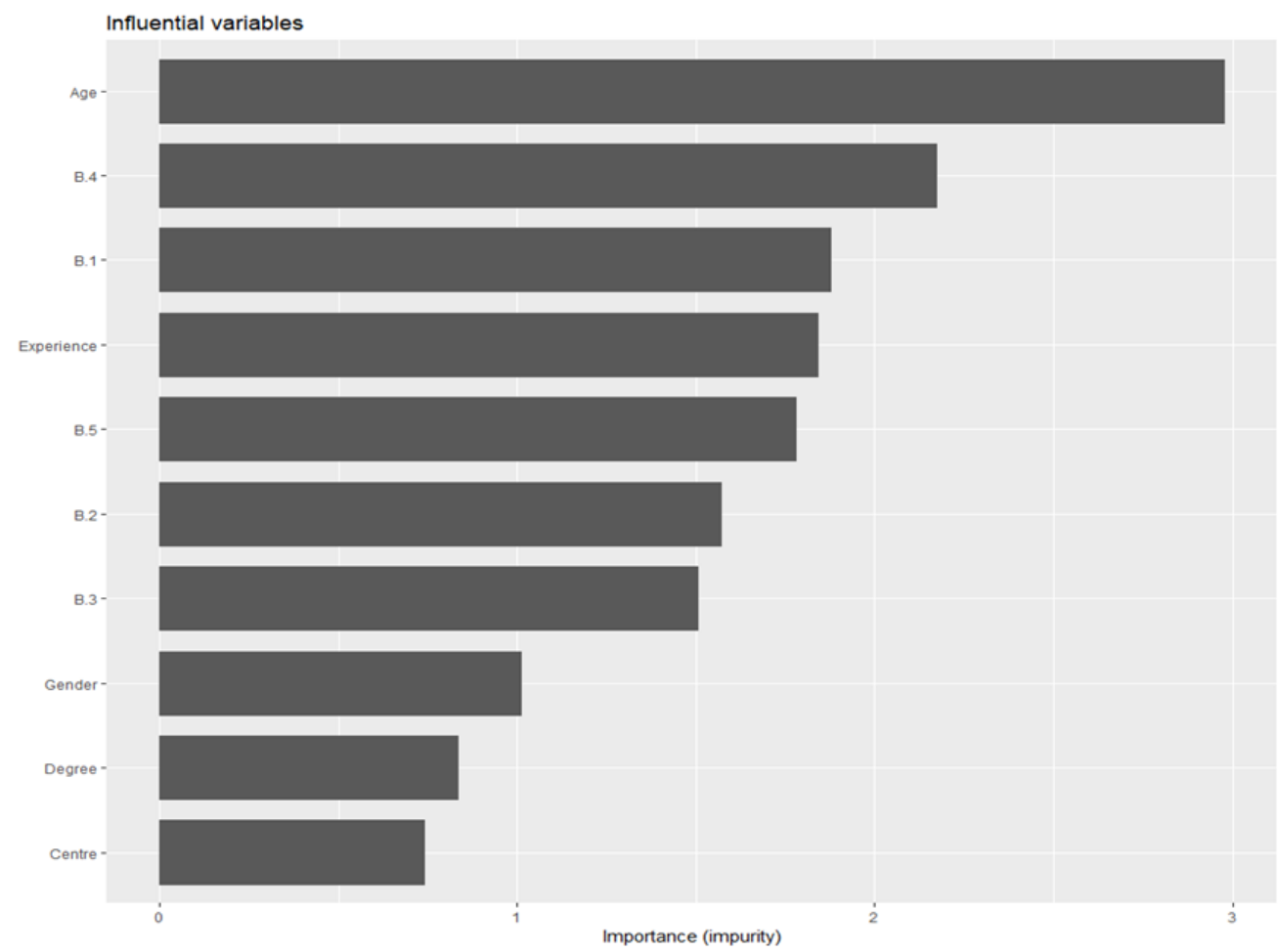

Figure 3. Variables affecting previous ICT training. 
Likewise, the calculation of the LIME algorithm allowed us to determine which variables contributed more to the establishment of the previous predictive model (Figure 4). For example, it was observed that subjects with a high command of B.3. and at least 10 years of experience contributed most to the "previous ICT training" variable. At the same time, other variables were also considered, such as teachers whose age is between 33 and 37 or those who have a good level of B.1. Conversely, teachers with a B.4. score of less than 56 points contribute less to this variable.

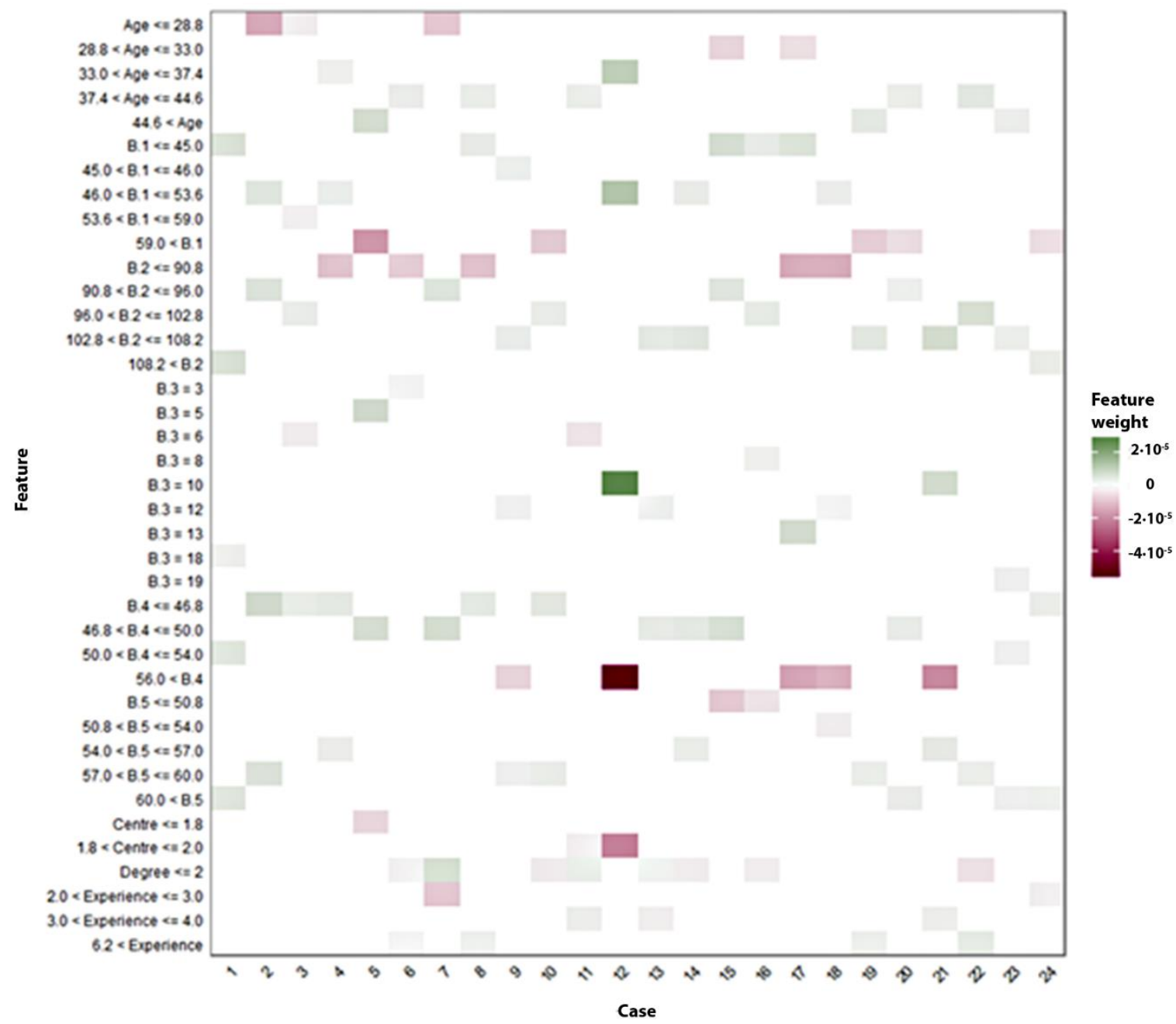

Figure 4. LIME for the variable previous training in ICTs.

\section{Discussion}

The development of digital teaching competence continues to be one of the educational challenges to be accomplished by the education system. In the case of the Lifelong Learning stage, teachers still have significant deficiencies in the different skills that develop it, which means we have to continue on the path of encouraging an initial and continuing training in this area. Therefore, it is a general concern at all educational stages $[24,25]$.

The results of the present study indicated a low level of digital competence by the teaching body. None of the dimensions included in digital competence obtained optimal results, which indicates that, as with other educational stages, continuing education teachers also present a low level $[33,34]$. In particular, the digital content creation dimension showed alarming results, as it was close to zero [37-39]. This indicates that teachers continue to use ICTs as a minimum support tool but do not have the self-efficacy to create their own digital content and share it with other peer users [28]. 
The research also explored whether the variable for prior ICT training directly determined whether teachers were more digitally literate. The results showed that there is no clear link between prior ICT training in most dimensions of digital competence, except for the communication and collaboration and digital content creation dimensions, which reaffirms the low results indicated in the descriptive analysis according to the sample of subjects analyzed, most of whom had not received prior ICT training. In view of this situation, the need to further encourage ongoing teacher training, as well as that of future teachers, is highlighted, since it is also at this stage that aspiring teachers must be equipped to interact with ICTs, and to work on a series of skills that will allow them to develop their digital competence. It is appropriate to focus on training that encourages the creation of content and the importance of establishing nodal networks among teachers, since it is through the exchange of experiences that reciprocal learning takes place and promotes much more motivating activity $[7,35,49]$.

Finally, the factors influencing the subjects' decision to opt for ICT training were analyzed deeply. Cross-validation analysis allowed us to know that the variable "age" is key and determine which subjects support technology training, as well as the areas related to security and information literacy, which are presented as fundamental reasons for promoting ICT training. Thus, the idea that normally, young teachers bet more on training in technological resources is corroborated. After this, the calculation of the H2o and LIME algorithms allowed us to know which variables have a greater importance in the ICT training of teachers, in which it was corroborated that young people with experience equal to or less than ten years are those who have previous ICT training. Those subjects between 33 and 37 were the ones who had greater importance in the analysis, a premise proven in this piece of work. It was also revealed that teachers with low scores in content creation and average scores in information literacy were those who were provided with the most previous ICT training [43], while some of the variables that have a smaller impact on prior ICT training were the nature of school or teachers with an average score in the area of security.

Finally, this research demonstrated the importance of continuing to encourage the development of digital competence of teachers, especially in Lifelong Learning. In order to contribute to the Sustainable Development Goals of Agenda 2030, it is essential to promote the improvement of education. As stated in Objective 4 of the previous defined goals, technological resources provide students with a range of new learning resources, which allow them to take up new opportunities to learn. Their ability to personalize learning will improve future outcomes [9].

\section{Conclusions}

The development of digital teaching competence remains a challenge to be addressed by the education system. Under the digital context in which we find ourselves today, society shall demand that the teaching body have enough digital skills to be able to share them with students of any age and educational stage.

In particular, students in the Lifelong Leaning stage take on special importance, as they are adults who have not interacted with technological resources from an early age, and therefore, their immersion in the digital panorama is more complex.

It is appropriate that educational institutions encourage training in digital teaching competence through the enhancement of ongoing teacher training, as well as an improvement in the initial training of future teachers. It is essential to address this aspect; thus, this is the only way to achieve a real change in teaching and learning.

Therefore, through this study, we have tried to establish an approach to the reality of the Lifelong Learning teachers, to try to contextualize for the research community the existence of this educational stage and the need that it presents at the same time. The study showed that the difficulties of teachers in initiating a real contact with ICTs still prevail. It also sought to elucidate that previous ICT training of teachers was not a determining factor in the level of competence shown, with the exception of the creation of their own content. This leads to the conclusion that the existing ICT training needs to be improved in order to increase the levels presented in teacher digital competence. In this sense, we 
should focus on the importance of continuing education for teachers, since, as this research proves, a large number of the teachers analyzed had not received any previous training in ICTs, which should not be the case in an educational system where technology is taking on an increasingly important role. In particular, teacher education should focus on clarifying the ways in which technology can be used in the classroom.

Nevertheless, it is appropriate to point out the limitations of the research, such as access to the sample of participants, since the number of teachers per Lifelong Learning center is reduced, and they come from different locations in Andalusia. Likewise, it is considered that the scale could have reflected more limited values in order to guarantee more reliable statistics. However, this research has a descriptive character and cannot be inferred from other contexts in Spain, since each autonomous community has similar curricular designs, but with different organizational and performance dynamics.

In terms of future lines of research, the community of researchers and teachers is encouraged to continue promoting the development of digital competence in different contexts and educational stages, with the aim of bringing together different experiences to help to determine the real state of development of digital teaching competence. It is highly recommended to continue studying the development of the same in the stage of Lifelong Learning, due to the scarcity of publications that take place in this educational stage.

In conclusion, the immersion of ICTs in the education system continues to be a challenge to be faced by the education system. In order to continue the path of improving education, as dictated in the Sustainable Development Goals, it will be necessary to continue developing teacher training in digital competence. To that end, it is necessary to establish a connection with educational institutions to encourage quality digital training in the teaching body, so that they can perform a functional and updated role to meet the demands of today's students.

Author Contributions: Conceptualization, E.G.A. and J.A.M.M.; methodology, G.G.G.; validation, J.L.O.M.; formal analysis, J.A.M.M.; investigation, E.G.A. and J.A.M.M; data curation, J.L.O.M; writing-original draft preparation, E.G.A. and G.G.G.; writing — review and editing, E.G.A. and G.G.G.; visualization, T.S.M.; supervision, T.S.M. All authors have read and agreed to the published version of the manuscript.

Funding: Scientific research project $(\mathrm{I}+\mathrm{D}+\mathrm{i})$ : Study and analysis on technological resources and innovation in teacher training in the field of Higher Education and its applicability in the development of the region of Santander (Colombia) Code: ISPRS-2017-7202.

Acknowledgments: To Fátima León Medialdea as a specialized translator of the manuscript. We also acknowledge the researchers of the research group AREA (HUM-672), which belongs to the Ministry of Education and Science of the Junta de Andalucía and is based in the Department of Didactics and School Organization of the Faculty of Education Sciences of the University of Granada.

Conflicts of Interest: The authors declare no conflict of interest.

\section{References}

1. Arzola, D.; Loya, C.; González, A. El trabajo directivo en educación primaria: Liderazgo, procesos participativos y democracia escolar. IE Rev. REDIECH 2017, 7, 35-41.

2. Starkey, L. A review of research exploring teacher preparation for the digital age. Camb. J. Educ. 2000, 50, 37-56. [CrossRef]

3. OECD. TALIS 2013 Results: An International Perspective on Teaching and Learning; OECD Publishing: Paris, France, 2014.

4. Prensky, M. Digital natives, digital immigrants. Horizon 2001, 9, 45-57.

5. Almenara, J.C.; Osuna, J.B. Los escenarios tecnológicos en Realidad Aumentada (RA): Posibilidades educativas. Aula Abierta 2018, 47,327-336. [CrossRef]

6. Escobar, S.D.; Rincon, V.M. Análisis Comparativo Sobre la Incorporación de las TIC"S en la Formación Profesional de las Universidades de Sabana de Occidente, Frente a la Pontificia Universidad Católica de Chile y la Universidad de Princenton de EEUU. [Working Paper]. 2018. Available online: http: //repositorio.ucundinamarca.edu.co/handle/20.500.12558/1006 (accessed on 15 January 2020). 
7. Trujillo, J.M.; Hinojo, F.J.; Aznar, I. Propuestas de trabajo innovadoras y colaborativas elearning 2.0 como demanda de la sociedad del conocimiento. ESE 2011, 20, 141-159.

8. Adams, S.; Cummins, M.; Davis, A.; Freeman, A.; Hall, C.; Ananthanarayanan, V. NMC Horizon Report: 2017 Higher Education Edition; The New Media Consortium: Austin, TX, USA, 2017.

9. United Nations-UN. Transforming Our World: The 2030 Agenda for Sustainable Development; United Nations: New York, NY, USA, 2015.

10. Comisión Europea. Comprender Las Políticas De La Unión Europea: Agenda Digital Para Europa. Available online: https://europa.eu/european-union/file/1501/download_es?token=317D0Fil (accessed on 16 January 2020).

11. Recomendación 2006/962/CE Del Parlamento Europeo Y Del Consejo, De 18 De Diciembre De 2006, Sobre Las Competencias Clave Para El Aprendizaje Permanente. Available online: https://eur-lex.europa.eu/eli/ reco/2006/962/oj (accessed on 30 March 2020).

12. Instituto Nacional de Tecnologías Educativas y Formación del Profesorado (INTEF). Marco de Competencia Digital; Ministerio de Educación: Ciencia y Deportes, Madrid, Spain, 2017.

13. Ilomäki, L.; Paavola, S.; Lakkala, M.; Kantosalo, A. Digital competence-An emergent boundary concept for policy and educational research. Educ. Inf. Technol. 2016, 21, 655-679. [CrossRef]

14. Ferrari, A. Digital Competence in Practice: An Analysis of Frameworks; European Commission Joint Research Centre (JRC): Seville, Spain, 2012.

15. ISTE. National Educational Technology Standards for Students; ISTE: Washington, DC, USA, 2008.

16. Ley 17/2007, de 10 de Diciembre, de Educación de Andalucía (LEA). Art. 105. Available online: https: //www.juntadeandalucia.es/boja/2007/252/1 (accessed on 30 March 2020).

17. García, J. Educación Comparada: Fundamentos y Problemas; Dykinson: Madrid, Spain, 1982.

18. Fernández Batanero, J.M.; Torres González, J.A. Actitudes docentes y buenas prácticas con TIC del profesorado de educación permanente de adultos en Andalucía. R. Compl. Educ. 2015, 26, 33-49. [CrossRef]

19. Instefjord, E.; Munthe, E. Preparing pre-service teachers to integrate technology: An analysis of the emphasis on digital competence in teacher education curricula. Eur. J. Teach. Educ. 2016, 39, 77-93. [CrossRef]

20. Alonso, S.; Aznar, I.; Cáceres, M.P.; Trujillo, J.M.; Romero, J.M. Systematic review of good teaching practices with ict in spanish higher education. Trends and challenges for sustainability. Sustainability 2019, 11, 7150. [CrossRef]

21. Medina, B.; García, V.J.L. La educación permanente y las plataformas web en España. Estudio comparado por comunidades de la presencia de la oferta formativa en línea. TEET 2014, 12, 15-27.

22. Cabero, J. Formación del profesorado universitario en TIC. Aplicación del método Delphi para la selección de los contenidos formativos. Educ. XX1 2014, 17, 111-132. [CrossRef]

23. Rodríguez, A.M.; Aznar, I.; Cáceres, P.; Gómez, G. Digital competence in higher education: Analysis of the impact of scientific production indexed in Scopus database. Espacios 2019, 40, 14.

24. Rodríguez-García, D.; Sánchez, F.R.; Ruiz, J. Digital competence, higher education and teacher training: A meta-analysis study on the Web of Science. Pixel Bit 2019, 54, 65-81. [CrossRef]

25. Almenara, J.C.; Gimeno, A.M. Information and Communication Technologies and Initial Teacher Training. Digital Models and Competences. Profesorado 2019, 23, 247-268. [CrossRef]

26. Centeno, G.Y.; Cubo, S. Evaluación de la competencia digital y las actitudes hacia las TIC del alumnado universitario. RIE 2013, 31, 517-536. [CrossRef]

27. Varela-Ordorica, S.A.; Valenzuela, J.R. Use of information and communication technologies as a transversal competence in teacher training. Educare 2020, 24. [CrossRef]

28. Escudero, V.G.; Gutiérrez, R.C.; Somoza, J.A.G.-C. Análisis de la autopercepción sobre el nivel de competencia digital docente en la formación inicial de maestros/as. REIFOP 2019, 22, 193-218. [CrossRef]

29. Colás, P.; Conde, J.; Reyes, S. The development of the digital teaching competence from a sociocultural approach. Comunicar 2019, 27, 19-30. [CrossRef]

30. Casillas, S.; Cabezas, M.; García, F.J. Digital competence of early childhood education teachers: Attitude, knowledge and use of ICT. Eur. J. Teach. Educ. 2019. [CrossRef]

31. Llorente, P.A.; Iglesias, E.C. Development of digital competence in the initial teacher education of early childhood education. Pixel Bit 2018, 52, 97-110. [CrossRef]

32. Méndez, V.G.; Martín, A.R.; Rodríguez, M.D.M. La competencia digital en estudiantes de magisterio. Análisis competencial y percepción personal del futuro maestro. Educ. XXI 2017, 35, 253-274. 
33. López, J.; Pozo, S.; Fuentes, A.; Trujillo, J.-M. Analytical competences of teachers in big data in the era of digitalized learning. Educ. Sci. 2019, 9, 177. [CrossRef]

34. Nowak, B.M. The development of digital competence of students of teacher training studies-Polish cases. IJHE 2019, 8, 262-266. [CrossRef]

35. Chandrasena, M. Lack of digital competence: The hump in a university-English for specific purpose-Classroom. IJSTR 2019, 8, 948-956.

36. Losada, C.; Rodriguez, J. Analysis of the digital education project (E-DIXGAL): The views of primary school teachers. Digit. Educ. Revolut. 2019, 36, 171-189. [CrossRef]

37. Amhag, L.; Hellström, L.; Stigmar, M. Teacher educators' use of digital tools and needs for digital competence in higher education. J. Digit. Learn. Teach. Educ. 2019, 35, 203-220. [CrossRef]

38. Fuentes, A.; Lopez, J.; Pozo, S. Analysis of the digital teaching competence: Key factor in the performance of active pedagogies with augmented reality. REICE 2019, 17, 27-42. [CrossRef]

39. Del Moral, M.E.; Villalustre, L.; Neira, M.D.R. Teachers' perception about the contribution of collaborative creation of digital storytelling to the communicative and digital competence in primary education schoolchildren. Comput. Assist. Lang. Learn. 2019, 32, 342-365. [CrossRef]

40. Guillén, F.D.; Mayorga, M.J.; Bravo, J.; Escribano, D. Analysis of teachers' pedagogical digital competence: Identification of factors predicting their acquisition. Technol. Knowl. Learn. 2020, 1-18. [CrossRef]

41. Araiza, M.J.; Pedraza, E. Discernment of teachers by gender in the use of ICT in the classroom based on digital competences. Espacios 2019, 40, 21.

42. Hinojo-Lucena, F.-J.; Aznar-Diaz, I.; Caceres-Reche, M.-P.; Trujillo-Torres, J.-M.; Romero-Rodriguez, J.-M. Factors influencing the development of digital competence in teachers: Analysis of the teaching staff of permanent education centres. IEEE Access 2019, 7, 178744-178752. [CrossRef]

43. Hung, E.S.; Sartori, A.S.; Marcano, B. Factors affecting the use of ICT in elementary school teachers in Colombia. Prism. Soc. 2019, 25, 464-487. [CrossRef]

44. Ilina, I.; Grigoryeva, Z.; Kokorev, A.; Ibrayeva, L.; Bizhanova, K. Digital literacy of the teacher as a basis for the creation of a unified information educational space. IJCIET 2019, 10, 1686-1693. [CrossRef]

45. Silva, J.; Usart, M.; Lázaro, J.-L. Teacher's digital competence among final year Pedagogy students in Chile and Uruguay. Comunicar 2019, 27, 31-40. [CrossRef]

46. Fernández, M.; Manzano, D. Analyzing differences in digital competence of Spanish students. Papers 2018, 103, 175-198. [CrossRef]

47. Omori, A.E.; Mabadeje, O.; Isah, A. The relevance of ICTS in the administration and organization of a functional continuing education program in Nigeria. Int. J. Interdiscip. Educ. Stud. 2015, 10,37-44. [CrossRef]

48. Korshunov, I.; Peshkova, V.; Malkova, N. Competitive strategies of vocational schools and universities in implementing continuing education programs. Vop Obraz 2019, 187-214. [CrossRef]

49. Zhao, Y.; Llorente, A.M.P.; Gómez, M.C.S. An empirical study of students and teaching staff's digital competence in Western China: Based on a case study of Gansu Agricultural University. In Proceedings of the 7th International Conference on Technological Ecosystems for Enhancing Multiculturality, León, Spain, 16-18 October 2019.

50. Valdivieso, T.S.; Gonzáles, M.Á. Competencia digital docente: ¿dónde estamos? Perfil del docente de educación primaria y secundaria. El caso de Ecuador. Píxel Bit 2016, 49, 57-73. [CrossRef]

51. Domingo, M.; Bosco, A.; Carrasco, S.; Sanchez, J.-A. Fostering teacher's digital competence at university: The perception of students and teachers. RIE 2020, 38, 167-182. [CrossRef]

52. Asencio, E.N.; García, E.J.; Redondo, S.R.; Ruano, B.T. Fundamentos De La Investigación Y La Innovación Educativa; UNIR Editorial: La Rioja, Spain, 2017.

53. Hernández, R.; Fernández, C.; Baptista, P. Metodología de la Investigación; McGraw-Hill: Mexico City, Mexico, 2014.

(C) 2020 by the authors. Licensee MDPI, Basel, Switzerland. This article is an open access article distributed under the terms and conditions of the Creative Commons Attribution (CC BY) license (http://creativecommons.org/licenses/by/4.0/). 